This is the version of the article accepted for publication in Journal of Asian Studies published by Cambridge University Press: DOI: https://doi.org/10.1017/S0021911819000172. Accepted version downloaded from SOAS Research Online: http://eprints.soas.ac.uk/30148

\title{
Revealing What is Dear: the post-earthquake iconisation of the Dharahara,
}

\section{Kathmandu}

Author: Michael Hutt, SOAS University of London

\begin{abstract}
On 25 April 2015 central Nepal was struck by a magnitude 7.8 earthquake which killed over 9000 people and displaced 2.8 million. The image of the Dharahara, a nineteenth century minaret which collapsed during the quake, quickly became for many Nepalis an iconic representation not only of the disaster but also of a national determination to recover and rebuild. Edward Simpson has argued that the aftermath of a disaster is 'a product of the longer history of a locality' and it is the aftermath 'that may reveal what is dear' (Simpson 2013: 53, 50). Drawing upon media and literary discourse in the Nepali language, this article asks why the Dharahara tower loomed so large in the Nepali imagination in the immediate aftermath of the April 2015 earthquake, rather than the country's severely damaged World Heritage sites, and why it became a rallying point for a resurgence of Nepali hill nationalism.
\end{abstract}

Keywords: Disasters, nationalism, heritage, Nepal, public memory, politics

thado nak samasta kantipurko he ucchata kritrim!

jyami lakh thiyau pavitra pasina he meghko ashram! seto stambha sukirtiko Dharahara! deu malai bida! 
he aglo prahari sari nagarko! deu malai bida!

Oh, man-made height, the nose held high of all of Kantipur!

Oh, refuge of the clouds, we [who built you] were a hundred thousand labourers, our sacred sweat!

Oh Dharahara, white pillar of glory, bid me farewell!

Oh towering guard of the city, bid me farewell!

(Siddhicharan Shrestha, Bhimsen Thapa Mahakavya, 11:14; (Shrestha 2073 bs: 53)) ${ }^{\mathrm{i}}$

Kathmadauko nautalle Dharahara!

Kathmadauko nautalle Dharahara!

The nine-storeyed Dharahara of Kathmandu!

The nine-storeyed Dharahara of Kathmandu!

(From the film 'Gorkhali' [https://www.youtube.com/watch?v=EYjmOhcMMSE])

\section{Introduction}

Disaster aftermaths have been the subject of a large number of empirical studies since the publication of Samuel Prince's groundbreaking Catastrophe and Social Change (1920). The emerging field of Disaster Studies is now also underpinned by a growing body of theoretical literature, whose authors invariably represent disasters generically 
not only as challenges to state authorities, which are expected to cope with the immediate needs of the affected population, but also as opportunities for groups within that population who wish to contest pre-existing structures of power. Notably, Pelling and Dill (2010) discuss the potential for a disaster to provide either a 'critical juncture' (a contestation of established political, economic and cultural power) or an 'accelerated status quo' (a successful concentration of that power). In many instances, the prospect of change appears to be looming in the immediate aftermath of a disaster, only for it to be eclipsed and disappear once more from view as the regime that held power before the disaster regains control and reinstates the political status quo ante, often in 'accelerated' form. This is perhaps because, ultimately, the impacts of a disaster do not represent a 'discontinuity of the social system' as much as a 'difficult extension of current life' (Albala-Bertrand 1993: 22).

Anthony Oliver-Smith has argued that 'the fundamental features of society and culture are laid bare in stark relief' by disasters (1996: 304), which 'often reveal the deeper social grammar of a people' (Oliver-Smith and Hoffman 2001: 10). But in his influential study of the political aftermath of the 2001 Gujarat earthquake, Edward Simpson disagrees. He describes the post-disaster period of 'abnormality and confusion' during which people are 'nice to one another, undifferentiated, as victims of a common calamity' as a 'short-lived and exceptional moment, marked by the failure of everyday grammar, rather than its refinement or condensation. It is instead the aftermath that may reveal what is dear' (Simpson 2013: 50). When the population affected by a disaster is ethnically, linguistically or culturally diverse and patterns of inequality that derive from this diversity are historically entrenched, political and cultural contestation become inextricably intertwined. A population that has suffered 
the impact of a disaster is inevitably more aware of the 'cultural battles' of the aftermath than those who come from outside to intervene (Simpson 2013: 96), and the traditions, artefacts, buildings and practices that turn out to be most 'dear' to the affected population may not be exactly what others expect them to be. In the case that will be considered here, the symbol that was adopted as a focal point for the most visible public expressions of grief was one that was widely seen, both domestically and internationally, as an architectural anachronism of little value or importance.

This discussion is concerned with the aftermath of the 2015 Gorkha earthquake in Nepal, and its relationship to questions of history, identity and public memory. Drawing upon literary and media discourse in the Nepali language, ${ }^{\mathrm{ii}}$ the discussion will revolve around the ruined stump of the Dharahara, a 203-foot tower first built nearly two hundred years ago in Kathmandu, which collapsed during the magnitude 7.8 earthquake that struck central districts of Nepal on 25 April 2015. The Dharahara was unloved by the generations of cultural historians who have documented the tangible and intangible riches of the Kathmandu Valley's heritage because of its non-native or imported architectural design. In 1912 it was described in the following uncomplimentary terms by a British visitor, the art historian Percy Brown:

Towards the centre of the city there arises, far above all other buildings, a stone tower or column, the most striking, but probably least interesting erection in Katmandu (sic). It is about 200 feet high, and is a notable landmark from all parts of the valley. Built by the Gurkha General Bhim Sen, it was not raised for any particular purpose but merely as a freak, and has long since been called Bhim Sen's folly (Brown 1912: 67). 
Similarly, the Dharahara merits no more than a single reluctant mention in Slusser's Nepal Mandala, widely regarded as the most authoritative study of the cultural history of the Kathmandu Valley, in a paragraph which also dismisses the 'new-style domed temple' that appeared in the Valley during the $17^{\text {th }}$ and $18^{\text {th }}$ centuries as a 'rustic and even pathetic imitation of Mughal architecture':

It was during the Shah period that the Dharahara, a tower imitating the Mughal minarets, was erected just outside the Kathmandu city walls, where its fanciful form still dominates the city skyline (Slusser 1982: 78).

However, the destruction of this 'fanciful' building had a greater and more immediate emotional impact upon a large section of the Nepali public than the loss of the temples and shrines of Nepal's World Heritage sites whose destruction was so grievously mourned by the wider world, ${ }^{\text {iii }}$ and at first even the destruction of over 750,000 homes, schools and other buildings across the fourteen hill districts that were most seriously affected. Why did the public of a country that had until 1990 been the world's last Hindu kingdom, a country that was still imagined by most of the wider world as culturally exotic and inherently religious, adopt as the symbol of its grief a plain, secular building built in a postcolonial Islamic style that had recently been made into a corporatized tourist attraction? Why did the Dharahara come to symbolise for so many Nepali citizens not only their country's losses but also its determination to rebuild, thus providing their political leaders with a well of public sentiment upon which they could draw to pursue their own post-disaster political agenda? In what follows I will attempt to answer these questions, but first it is necessary briefly to explore the history of the monument in question and its possible meanings for past and present generations of Nepalis. 


\section{The creation and meaning of the Dharahara}

In 1816, after two years of sporadic fighting in Nepal's foothills, the troops of the British East India Company achieved victory over the army of Gorkha, the rapidly expanding hill kingdom whose Shah kings assembled the modern nation-state now known as Nepal. This military defeat marked the end of some 70 years of rapid Gorkhali expansion, during which the Indo-Aryan elites of the hills extended their domination of west and central Nepal to new territories in the east. The political and cultural ascendancy of this elite endures today, and is reflected in its disproportionate representation in public office, land ownership and economic activity.

From 1806 until his dramatic fall from power in 1837, the mukhtiyar [Commander-in Chief of the Army] Bhimsen Thapa was the most powerful man in Nepal. ${ }^{\text {iv }}$ Sources differ on whether the Dharahara he built in the grounds of his mansion, the Bagh Darbar, was the first or second of two similar structures. ${ }^{v}$ In 1832 the British Resident in Kathmandu, Brian Hodgson, recorded the existence of two minarets in this locality. ${ }^{\mathrm{vi}}$ According to Hodgson, the smaller of the pair was named after Bhimsen Thapa and built in the garden of the Bagh Darbar, and the taller one, a structure with a broader base known as the upper or upallo dharahara, was built by or for the junior Shah queen Maharani Lalit Tripura Sundari, ${ }^{\text {vii }}$ just to the north. The towers are said to have been built in $1824 / 5$ and 1832 , but there is some uncertainty about which was built on which date. ${ }^{\text {vii }}$ During a major earthquake in 1833, one of the two Dharaharas collapsed completely and was not rebuilt, while the other was only partially damaged and was quickly restored. It was most probably the larger of the two towers (the one named for the Queen) that was rebuilt, and not the smaller one, because at this stage of Nepali 
history Bhimsen's political star was waning. ${ }^{\text {ix }}$

It is widely believed that the original towers were modelled on monuments in India such as the minarets that stand at the four corners of the Taj Mahal complex at Agra, or the Qutb Minar in Delhi. Unfortunately, we have no way of knowing what the creators of the Nepali versions of these monuments intended in terms of their meaning and purpose. Sidewalkers (P) Ltd, the company which has managed the Dharahara site since 2004/5 (see below), erected a number of information signboards in both English and Nepali around the base of the tower which recorded a version of its history. On these signboards (which remained in situ for three years after the 2015 earthquake) it is stated that the Dharahara's main purpose was to enable the state and city authorities to summon people to gather on the Tundikhel (the military parade ground to the northeast of the tower) to hear government announcements, and that it showed 'the religious harmony between Hindu, Muslim and Christian faiths'. It offers as supporting evidence for this latter assertion the fact that the topmost floor contains a Shiva shrine, that the tower is built in Mughal style, and that the railings around its base are in a European style. While the historical function of the tower as a public gathering-point is well attested in historical sources, this does not shed much light on the originally intended symbolism of the structure; and the conception of the Dharahara as a symbol of religious unity is not a notion I have come across in any other source.

Of course, the level of convergence between the original intended meaning and the contemporary public understanding of a monument will inevitably vary from structure to structure. Nelson and Olin record that Alois Riegl, the first conservator general of monuments in the Austro-Hungarian empire, distinguished between the 'intentional 
monument', whose 'significance is determined by its makers' and the 'unintentional monument', which is the product of later events. Some monuments are created for a political, cultural or religious reason and invested with a specific meaning at the point of their creation, which they carry, essentially unchanged, down through the generations. Others may be created for a more functional purpose, but then acquire significance and meaning because of events that take place after their founding. A third category of monuments may be invested with one specific meaning or set of meanings at the point of their creation, but then acquire a different set of meanings for later generations-perhaps because their original meaning has become objectionable or contentious due to political or cultural shifts in the society that surrounds them, or simply because their originally intended meaning has been forgotten or misremembered (Nelson and Olin 2003: 1-2). Finally, there are monumental ruins: 'the memory left by a monument after it has been destroyed: a memory of absence' (Elsner 2003: 211).

At the time of its creation the first Dharahara was, as 'a deposit of the historical possession of power' (Phillips 2003: 281), surely an 'intentional monument'. Given the historical context of its creation and the identity of its patron, it seems reasonable to interpret its intended meaning in terms of defiance and nationalistic pride, directed at the British East India Company that had defeated Bhimsen Thapa's forces and installed a British Resident in Kathmandu. Although it may be conceived of as a 'public history site' (Walkowitz and Knauer 2009) by some, it is probably more accurately described as a symbol of 'state-sponsored triumphalism' (Winter 1999). ${ }^{\mathrm{x}}$ As Anne Rademacher observes in her study of riverside monuments in Kathmandu, 
Although the British never established full formal control in Nepal, colonial power had clear effects, and complicity and cooperation with the British went a long way toward reproducing state power. Nevertheless, the fact of independence has combined over time with narratives of bravery and defiance to form a fundamental theme in official constructions of Nepal's national history and identity (Rademacher 2009: 232).

Once it had been reconstructed in the wake of the 1833 earthquake, the remaining Dharahara remained intact, 'visible from afar and overlooking the entire valley' in the words of an early foreign visitor, Prince Waldemar of Prussia, until the next major earthquake struck Nepal in 1934, bringing the Dharahara down again. The Rana artist and litterateur Balkrishna Sama (1903-81) recorded his first sight of its ruins in his memoirs:

With great sadness I took a picture of the breast of the Tundikhel, split wide open. When I saw the Dharahara cut down, with only the bottom four storeys remaining, it looked to me like some heroic Nepali whose head had been cut off at [the battle of] Nalapani but who still stood guard at Bhimsen Thapa's gate as a murkutta [headless ghost] (Sama 1972/3 (2029 b.s.): 213-4)

A photograph in the English translation of the only detailed account of the 1934 earthquake shows the site surrounded by scaffolding for repairs (Rana 2013: 136ff.). The new structure, completed in 1936, had nine storeys rather than the original eleven, and a gallery was added to its upper portion. As the Sidewalkers signboards correctly state, in the years that followed a bugle was sounded from the Dharahara to call the army to assemble on the Tundikhel or to call civil servants to the palace armoury, and also to summon the populace for important announcements. ${ }^{\mathrm{xi}}$ 
Pierre Nora has argued that 'modern societies' live within a 'historical' rather than a 'memorial' consciousness of time and that 'memory has been dissipated by the incursions of the modern world'. However, the residues of this memory have nonetheless coalesced around particular lieux de memoire, which Nora defines as 'monuments of history torn away from the movement of history, then returned; no longer quite life, not yet death, like shells on the shore when the sea of living memory has receded' (quoted in Wood 1994: 128). So there the Dharahara stood for another two generations, half torn away from history as a residual artefact of a half-forgotten Gorkhali national pride, while the urban fabric of Kathmandu changed rapidly all around it, especially after the political and economic liberalisations of the 1990s. In 2004/5 (2061 b.s.) the management of the site was passed to Sidewalkers Pvt Ltd., which appears to have been established for the sole purpose of managing the Dharahara, reflecting a Nepali edition of the 'growing role given to public history sites for state patriotic veneration, corporate financial gain, or urban renewal "heritage" entertainment in the worldwide spread of the modernist enterprise' (Walkowitz and Knauer 2009:9). Its management allowed members of the public to climb the Dharahara's internal staircase to take in the panoramic view from the top for a fee of 55 Nepali rupees, and a small public garden, a café and a ticket office were established at the foot of the tower. It became a popular attraction for Nepali sightseers, including people from outside the capital valley. A Sidewalkers employee to whom I spoke at the site in 2016 informed me that $150-200$ people used to ascend the tower on ordinary days, and up to 300 on holidays. ${ }^{\text {xii }}$ The experience of climbing the Dharahara to admire the view of Kathmandu from its balcony became a heritage commodity that possessed something of the symbolic meaning of a visit to the Eiffel Tower, as described here by Barthes: 
...by its very position as a visited outlook, the Tower makes the city into a kind of Nature; it constitutes the swarming of men into a landscape, it adds to the frequently grim urban myth a romantic dimension, a harmony, a mitigation; by it, starting from it, the city joins up with the great natural themes which are offered to the curiosity of men: the ocean, the storm, the mountains, the snow, the rivers (Barthes 1964: 241).

\section{Public and media reactions to the fall of the Dharahara}

The Dharahara collapsed for the second (or possibly third) time between 11.56 and 11.57 a.m. on Saturday 25 April 2015, killing and injuring a large number of people, many of whom were inside the tower when the earthquake struck. The news of its destruction had a powerful emotional impact on many Nepalis, including people living outside the capital, many of whom knew it only from photographs. The journalist Sarala Gautam, who at the time of the earthquake was travelling in Jajarkot, a western hill district that was largely unaffected by it, reported that it was when local people heard that the Dharahara had fallen that they understood the scale of the calamity: they then realised that 'the disaster was not small'. It became clear to Gautam that for many Nepalis in the western hills, almost regardless of their ethnicity, caste or gender, the Dharahara was still the pre-eminent symbol of their capital city's, and therefore their nation's, identity. Gautam recalled many conversations with people whose first comment when they heard she had come from Kathmandu was 'Oh, I hear the Dharahara fell down (e, dharahara dhalyo re)':

'It's so sad' she said, 'The Dharahara has fallen.' I asked her if she had ever visited Kathmandu. No, she said, she'd seen it on Facebook. Nowadays Facebook shows everything. She was Kalpana BK, aged 27. Her husband was working in Malaysia. They talked on a mobile when she went to a shop in 
Chaurajahari that had the internet running. She told me that she had been planning to go to Kathmandu and see the Dharahara when her husband returned from Malaysia. But now her wish had collapsed (Gautam 2015)

The hundreds of first-person accounts of the 2015 earthquake that appeared in Nepalilanguage newspapers, magazines and social media in the aftermath typically contain an early and very specific reference to the moment when their authors received the news that the Dharahara had fallen. For these people too, this was the moment when the sheer scale and gravity of the disaster first impressed itself upon them. Writing less than three weeks after the earthquake, the senior journalist Kishor Nepal argued that the collapse of the Dharahara had had a massive psychological effect on the people of the capital city, most of which escaped the disaster comparatively unscathed:

...although some important places, bazaars and settlements in Kathmandu suffered extensive damage and saw a major loss of life and property, most parts of the inner city remained secure. Even so, the level of fear among the people of Kathmandu is very high and very dense. The main psychological reason for this fear is the shattering of the Dharahara, a tall minaret erected as a show of power in imitation of the Islamic empire. If the Dharahara had not broken and if there had not been damage in and around Hanuman Dhoka, the centre of state power, the current level of dread would not have spread through people's minds (Nepal 2015).

All quarters of the Nepali news media understood this quickly, regardless of their political leanings, and gave more coverage to the collapse of the Dharahara than to the destruction of any other building. Thus, the Dharahara quickly became the icon of Nepali resilience and determination to rebuild. When I visited Kathmandu in July 2015 (two months before the promulgation of the new constitution and the 'Indian blockade' that followed) many young people could be seen wearing T-shirts bearing the image of 
the Dharahara and various versions, in both English and Nepali, of the slogan 'we will rise again'. The iconic image of the tower also became a popular design for tattoos on arms and legs in the growing number of tattoo parlours across the city: some young Nepalis had clearly been affected by its destruction so much that they were willing to have its image inscribed permanently on their bodies (Lotter 2018).

The Dharahara also featured extensively in Nepali-language poetry-the medium in which public sentiment finds its quickest expression in Nepal—during the immediate aftermath of the 25 April earthquake. Of the five poems published in the literature section of the influential online newspaper Setopati within 24 hours of the disaster, three were inspired by the destruction of the Dharahara. Under a photograph of the Dharahara captioned, in English, 'Pray for Nepal', Acharya Prabha's poem addressed the Dharahara with the informal second person pronoun timi. The poem described the tower as 'the grandeur and pride of the country' and suggested that all should apply a tika from its ruins to their foreheads and then wash them off to create a 'heap' (dhiko) of unity.

Where might we search for you now?

With what touch can I meet you?

With what water can I slake

My thirst for you?

Oh, my tall Dharahara,

Why did you become like this today,

So far far away from us? ${ }^{x i i}$

A second poem, by Niru Tripathi, bade the Dharahara farewell, using an Urdu salutation 
(albida) that suggested an awareness of its Mughal architectural ancestry. The poem asserted that 'an age has ended with you' and ended in lines of reproach:

Why did you melt away and collapse completely, leaving everything behind?

I did not think you were so selfish.

Why did you put all your beloved ones to sleep on a single pyre? ${ }^{\text {xiv }}$

Anger quickly followed fear in the public response to the earthquake, and this was mainly directed inward at the national government for what was seen as a callous and uncaring lack of preparedness, and an inadequate response. Nepal's vulnerability to art theft is well known, and media reports of the disappearance of religious icons from temples and shrines cause anger and outrage at regular intervals. In the immediate aftermath of the quake, many reports were published online of the looting of archaeological remnants, in which it was alleged that government servants colluded. In one such report, it was alleged that a driver employed by a senior civil servant was seen at the site of the collapsed Dharahara collecting bricks which dated from the reconstruction of the tower carried out in 1936 during the reign of Juddha Shamsher Rana, in order to sell them on the international market. ${ }^{\mathrm{xv}}$ One year later, it was reported on the same online news site that bricks from the Dharahara were being taken to a dumping site and that government officials were being dismissive of public concern about this. $^{\text {xvi }}$

Many newspaper op-eds blamed Nepali society itself for inviting the calamity, asserting repeatedly that the earthquake was a consequence of human venality, conceit and ambition. This was often seen as manifesting itself in the building boom that has taken place in the Kathmandu Valley since the 1990s, and particularly in the construction of 
tall buildings. But it was also seen in the alleged weakness of political leadership. To cite one typical example:

The Dharahara fell in the 1934 earthquake too, and was reconstructed. But less than 82 years had passed before it fell again. If it is to be re-erected, now we must consider how strong and firm it should be. This has symbolic meanings too. We should not build a Dharahara that is weak like the nation's leaders. For the sake of the nation's history the Dharahara must symbolically foster strong leadership (Sitaula 2015).

It was as if the case of the Dharahara was providing a focal point for widespread public frustration with the Nepal government's response to the earthquake. A monument that for so many represented ordinary citizens' patriotic pride had not been properly maintained, let alone strengthened to withstand earthquakes, by the politicians who sought their votes. Not only that: the same venal politicians had sold it to a private company for commercial exploitation. The anonymous author of an op-ed article published in the Kathmandu Post three and a half months after the earthquake blamed the death toll on the decision to open the tower to the public in 2005 , which $\mathrm{s} / \mathrm{he}$ believed was inspired purely by motives of profit: 'the Dharahara... was never meant to be a sightseeing tower for the people' ${ }^{x v i i}$ In his lament for the Dharahara, addressed, like so many poems, to the building itself, Santosh Chimariya (2015) sees this as a desecration:

In the course of time, even you were engulfed by the open market epidemic. Your decrepit 200-year-old body was opened for people to climb for a payment. Nobody was at all interested in your restoration, repair or conservation, but permission was given to those who wished to climb onto your shoulders and reach your summit for a view of Alakapuri Nagari [the capital city of the mythical Yakshas] if they paid a fee. 
It is not certain how many people were killed by the collapse of the Dharahara. In fact, news reports did not dwell on these fatalities or enumerate them very consistently. ${ }^{\text {viii }}$ If the Dharahara was going to serve as an icon for a popular movement that would rebuild Nepal anew, it needed not only to kindle anger but also to offer hope. Thus, the Nepali news media carried numerous stories about the survivors of its fall, which provided the backdrop for tales of survival, resilience and hope for the future.

The story of 18-year-old Prashamsa Shrestha, published in the Nepali-language Nagarik newspaper a year after the earthquake, serves as an example. Prashamsa left her home in Dhobighat with her elder sister Shanti on the morning of the quake. As it was a Saturday, they planned to roam around the city taking photos on their phones to upload onto Facebook. They headed first for the Dharahara, climbed slowly to the top, and photohraphed the view. When the earthquake struck, Prashamsa was on the balcony, and she clung to the railing as the tower collapsed beneath her. A man named Raju Lama extracted her from the debris and put her into an ambulance. She has since undergone multiple operations on her leg and can now walk slowly (all costs of her treatment have been borne by Basanta Chaudhary, of the leading Nepali industrialist family.) Now she is determined to study BSc Nursing. ${ }^{\text {xix }}$ The report is typical of the genre: most of the survivors whose stories are told were on the viewing balcony when the earthquake struck; they all have courage and optimism for the future; and the stories often contain examples of heroic rescue and sometimes, as in this case, philanthropy.

Since its destruction the form of the Dharahara has been recreated in both real and virtual spaces. Within a few months, a miniature Dharahara was built at the traffic intersection immediately opposite the site of the original. One year later, it was reported 
that a 21-metre replica was being built in the grounds of a secondary school in Nawalparasi district, at an estimated cost of Rs 1.5 million. ${ }^{\mathrm{xx}}$ Many others have been built since, including a 20-foot replica beside the Prithvi Highway near Malekhu. In cyber space too, the Dharahara lives on. It has its own Twitter identity (@DharaharaKTM) where images of replicas created in various locations have been posted. In the wake of terrorist attacks in Paris in November 2015, one Nepali Twitter user posted an image of the Dharahara mounted on top of the Eiffel Tower, with the caption 'Pray for France'. Youtube also carries numerous Dharahara-related videos. These include a presentation which claims that the two original Dharahara towers survived until 1934, and presents them as Nepal's 'Twin Towers', thus attempting to draw a parallel with the destruction of the World Trade Centre in New York in 2001 and to identify the Dharahara site as Kathmandu's own 'Ground Zero':

Now our nation lost both of them in Earth Quakes. Please watch this video to create awareness to rebuild both of them. They are pride of Nepal and Nepali People, Two chambers in the heart of Kathmandu. ${ }^{\mathrm{xxi}}$

At least one attempt was made to profit commercially from the outpouring of public sentiment. A full-page colour advertisement for NCell (Nepal's largest mobile phone network) appeared in the Nepal Patrika weekly news magazine of 28 June 2015, showing the form of the ruined Dharahara shaped in clay turning on a potter's wheel, with a potter's hands upon it. The text beneath the image read:

IF WE UNITE IN BELIEF AND ACTION, WE WILL BUILD OUR NEPAL. Although wounded at heart, our courage is not diminished. Our sleep has flown away but our dream is yet unbroken. The present is wounded but hope of a future has not died. Turning the present into history... aiming at a new future, we will walk together, we Nepalis. 


\section{The political context of the Dharahara's fall}

The discourse generated by the destruction of the Dharahara needs to be understood against the backdrop of ongoing sociocultural and political contestation in Nepal, to explain which a brief excursus is necessary at this point in the discussion.

Table 1: Nepal: Outline Political Chronology

\begin{tabular}{|c|c|}
\hline $1768-9$ & $\begin{array}{l}\text { Conquest of the Kathmandu Valley by Prithvi Narayan Shah, King of Gorkha, leading } \\
\text { to the 'unification' and creation of modern Nepal }\end{array}$ \\
\hline 1816 & $\begin{array}{l}\text { Gorkha forced to accept a treaty reducing its territorial scope and power after defeat } \\
\text { in the Anglo-Nepalese Wars }\end{array}$ \\
\hline $1846-1951$ & $\begin{array}{l}\text { Rana family autocracy established in a coup and maintained with increasing reliance } \\
\text { on the British colonial power in India. }\end{array}$ \\
\hline $1962-90$ & $\begin{array}{l}\text { Panchayat regime of 'partyless democracy' under Kings Mahendra and Birendra, after } \\
\text { Mahendra dismisses Nepali Congress administration elected in } 1959 .\end{array}$ \\
\hline 1990 & $\begin{array}{l}\text { First Jan Andolan ('People's Movement') leads to the abolition of the Panchayat } \\
\text { system. Minority ethnic groups organise to press for greater inclusivity. }\end{array}$ \\
\hline 1991-2002 & Series of short-lived party-led governments \\
\hline $1996-2006$ & Maoist 'People's War' \\
\hline $2006-7$ & $\begin{array}{l}\text { Second Jan Andolan, against King Gyanendra, leads to a Comprehensive Peace } \\
\text { Agreement between the Maoists and the parliamentary parties. An Interim } \\
\text { Constitution is promulgated and Nepal is declared a secular state. }\end{array}$ \\
\hline 2008 & $\begin{array}{l}\text { Election of first Constituent Assembly. Nepal is declared a republic; the monarchy is } \\
\text { abolished. However, the Constituent Assembly fails to deliver a new constitution and } \\
\text { is dissolved in } 2012\end{array}$ \\
\hline 2013 & Election of second Constituent Assembly. \\
\hline \multirow[t]{3}{*}{2015} & $\begin{array}{l}25 \text { April: Gorkha Earthquake, followed by several months of smaller earthquakes and } \\
\text { aftershocks. }\end{array}$ \\
\hline & 20 September: promulgation of new constitution introducing a new federal structure \\
\hline & $\begin{array}{l}\text { October: the 'blockade' of Kathmandu, mounted by Madhesi organisations with } \\
\text { Indian support, begins. It lasts until the following spring. }\end{array}$ \\
\hline
\end{tabular}

A century of Rana family autocracy ended in 1951, soon after the departure of the British colonial power from the Indian subcontinent. During the 1950s, the palace, the new political parties and the feudal landlords of the displaced old order jostled for power. The Nepali Congress Party, led by the charismatic BP Koirala, appeared to have come out on top when it won a majority in the elections of 1959. 
However, King Mahendra dismissed the Congress government less than two years after its election to power and established a new political system, the panchayat vyavastha. Political parties and organisations advancing sectional interests and agendas were banned under this regime, and development became the all-encompassing theme of government programmes. Nepal benefited from its strategic location during the Cold War, receiving massive quantities of aid, and literacy and public consciousness of the wider world grew in leaps and bounds. Panchayat nationalism set out to homogenise Nepal's national identity around the three pillars of the monarchy, the Nepali language and Hinduism, and political and cultural dissent was harshly suppressed.

In 1990 a popular movement - the first Jan Andolan-forced King Birendra to dismantle the Panchayat system and give way to the re-establishment of multi-party democracy. A generation of politicians who had struggled for decades under the Panchayat regime felt that their time had come. A new constitution was promulgated and the Nepali Congress Party won the first general election. The opposition was dominated by parties espousing various forms of communist ideology, along with other more conservative elements who were disgruntled by the constitutional change.

The early 1990s saw a major upsurge in the claiming of civil rights by the marginalised —notably the Adivasi Janajati ('indigenous nationalities'), Madhesis, Dalits, and women. But the new democratic dispensation failed to deliver on its promises. The political parties spent more time and energy competing with one another for power, patronage and commission, and much less on implementing the promises in their manifestoes.

Partly because of this, war broke out between the Nepal Communist Party (Maoist) and the Nepali state. This began in the mid-western hills in 1996 but had spread to almost 
every district of Nepal by 2003. Over 16,000 lives were lost during a ten-year period, and Nepal saw severe abuses of human rights. In 2001, the family of King Birendra was massacred in Narayanhiti palace, probably by Crown Prince Dipendra, and King Gyanendra took the throne. Within five years he had succeeded in alienating both the mainstream parties and civil society so much that they made common cause with the Maoists against him.

The war ended in 2006 when the Maoist insurgents and the parliamentary parties aligned themselves against the monarchy. In 2007 an Interim Constitution was promulgated and a new national anthem was adopted (see Hutt 2012), and in 2008 a Constituent Assembly was elected to draft a new constitution for a secular, democratic, federal republican state of Nepal. The new constitution, it was promised, would ensure greater inclusivity and representation in a country where people other than men from among the upper castes (Bahuns and Chetris) of the hill regions and the upper strata of the Newar society of the Kathmandu Valley had been largely excluded from avenues of advancement and power. The Maoists, who had now renounced armed struggle, confounded expectations by becoming the largest party in the Constituent Assembly. At its first meeting, in May 2008, the Assembly voted to abolish the Shah monarchy.

Although the Constituent Assembly elected in 2008 was probably the most representative legislative body ever established in South Asia, its proceedings and decisions quickly came to be dominated once again by political party leaders, who failed to agree on a range of key issues, including the form of government and the structure of the new federal state, which Adivasi Janajati activists insisted should be determined by the geographical distribution of minority ethnic groups. Having failed to deliver a constitution despite extensions to its original two-year term of office, the 
Constituent Assembly came to the end of its life in May 2012. After an 18-month interregnum, during which Nepal was governed by an administration headed by its Chief Justice, a new Constituent Assembly was elected in November 2013. No party achieved an overall majority in these elections, but the Nepali Congress emerged as the single largest party and the Maoists' share of the vote fell dramatically, leaving them in third place. A new government based on a coalition of the Nepali Congress Party and the Nepal Communist Party (Unified Marxist-Leninist) was formed in February 2014, with Sushil Koirala of the Nepali Congress Party as Prime Minister.

This government was in power when the earthquake struck and it was not well prepared to deal with a disaster on such a scale. The most immediate response came from the Nepali citizenry (particularly the young), the Nepal Army, and the Indian government. On the basis of a Post-Disaster Needs Assessment, international agencies and donor countries quickly pledged $\$ 4.4$ billion of emergency aid to enable rescue and relief in the short term and reconstruction in the longer term. For their part, the leaders of the four biggest political parties decided that the completion of the constitution should now be prioritized and fast-tracked. A 16-point agreement was formalized between them for this purpose on 8 June.

The 'fast-tracked' constitution that was promulgated on 20 September 2015 was greeted with celebrations in the hills of Nepal, but with public protests and brutal police reactions in the plains. This was because it had failed to deliver on the long-held promise of a fairer deal for the Madhesis, the people of the southern Tarai plains. Madhesi political organisations resorted to doing one of the few things they can do to put pressure on the government of Nepal: they blockaded the main arterial road via 
which Kathmandu receives the bulk of its key supplies. As a result, there were severe shortages of key commodities in the capital, particularly of fuel. Now led by Khadga Prasad Sharma Oli of the Nepal Communist Party (Unified Marxist-Leninist), who had replaced Sushil Koirala of the Nepali Congress Party as Prime Minister in October 2015, the government resorted to nationalistic rhetoric in response, asserting loudly and repeatedly that the Indian government was 'blockading' Nepal in support of Madhesi demands. This led to a serious deterioration in relations - not only between the governments of India and Nepal, but also between the populations of Nepal's hills and plains. The political potency of the Dharahara as a symbol of nationalism (and arguably of Gorkhali hill nationalism at that) was not lost on the government of the day.

\section{Rebuilding the Dharahara}

In April 2016 Nepal's Prime Minister, Khadga Prasad Sharma Oli, attended a function at the site of the Dharahara to mark the first anniversary of the quake. A minute's silence was observed, and the candle display laid out in nearby Basantapur Square on the same occasion featured the outlines of the Kasthamandapa ${ }^{\mathrm{xxii}}$ and the Dharahara, the two buildings that had by this time acquired the status of iconic representations of the disaster of twelve months before.

A Dharahara Reconstruction Campaign had been launched by the Prime Minister in February 2016. The Prime Minister declared, 'The Dharahara is the symbol of our unity and strength; it is an identity of all Nepalis. It needs to be reconstructed through funds collected from each individual' (Ojha 2016). This sentiment was strongly endorsed by the editorial of the government-owned daily newspaper Gorkhapatra on 18 February: 'Every Nepali will feel that they have made their own contribution to the 
reconstruction of the Dharahara. There is no doubt at all that this will lead to the development of an enhanced sense of nationhood.' Addressing the Legislative Assembly in June, the Prime Minister declared that the Dharahara was a parichay, a characteristic feature, of the nation: it was Nepal's equivalent to 'the towers that appeared when other nations' names were mentioned'. He said that it would be wrong to restore the Dharahara using funds from international aid or from the national treasury, and that it should be reconstructed from the level of the people so that people would think of it as 'my Dharahara' xxiii Shortly after the first anniversary of the quake, an announcement was posted on the homepage of the National Reconstruction Authority website headed 'The "My Dharahara I will Build It" Campaign' (Mero Dharahara Ma Aphai Banaunchu Abhiyan). This gave details of the bank account to which donations should be submitted and exhorted the Nepali people to contribute to the restoration of the Dharahara, which it described as 'a symbol of the selfhood and pride (apnatva ra svabhiman) of the Nepali people (janata)'.

However, one month after Prime Minister Oli had called on the public to donate, Republica newspaper reported that not a single rupee had been received, except for the money donated by the Prime Minister and other ministers as one month of their salaries. The Republica reporter attributed this to 'lack of trust on the government'. ${ }^{\text {xiv }}$ It may also have been related to a controversy over Sidewalkers' ownership and management of the site: "Why should the people apply their money to build Dharahara to feed businessmen? Give us an answer, Prime Minister' read one posting on Facebook, which further alleged that the contract between Sidewalkers and the Kathmandu Municipality made the former responsible for its maintenance, repair and reconstruction. ${ }^{\mathrm{xx}}$ Nyaupane (2015b) gives a highly critical account of the process by which Sidewalkers 
acquired the contract to manage the site and of its custodianship thereafter. He is particularly critical of the alleged lack of insurance cover for visitors to the building, which he claims was allowed to lapse within two years of the signing of the original contract, and blames the Kathmandu Municipal Council for its neglect and lack of care. More broadly, objections were raised in the press and on social media to the expenditure of public funds on the restoration of a mundane monument when many quake-affected districts were still waiting for much-needed relief.

The Director of the Government of Nepal's Department of Archaeology, Bhesnarayan Dahal, is quoted by one source as saying that the seven Valley sites listed as World Heritage [vishva sampada] sites $^{\mathrm{xxvi}}$ were the first priority, and only after that would decisions be taken about the reconstruction of 'national heritage' (rastriya sampada) such as the Dharahara. However, Nepal's political leadership forged ahead with the idea of rebuilding the Dharahara through public subscription, and in August 2016 plans were unveiled for a new Dharahara. According to newspaper reports, this would stand beside the remains of the old tower, which would be maintained as an earthquake memorial. The new Dharahara would be restored to its pre-1934 dimensions, standing 245 feet tall with two internal elevators. The new monument and adjoining park would cover a total area of 42 ropani, and include a three-storey parking lot. ${ }^{\text {xxvii }}$ In September 2018 the contract for the building of a new Dharahara was awarded to a Nepali construction company and its Chinese 'joint venture partner' and the foundation stone was laid by the Prime Minister on 26 December. ${ }^{\text {xxviii }}$

\section{A public dichotomy}


The aftermath of the 2015 earthquake saw a resurgence of national feeling in Nepal after a ten-year period during which national identity had been a contested concept. Calls for unity and a common effort to enable Nepal to 'rise again' issued from every political quarter, though they were differently nuanced, with a significant number of voices calling for the building of a 'new Nepal' that would sweep the old order away.

A fragile government that was reluctant to keep its predecessors' promises to its minorities sought to exploit popular majoritarian understandings of history, heritage and nationhood. Its Prime Minister recognised the particular potency of the Dharahara for the hill communities that formed his party's main constituency, and sought to amplify the public mourning for a building that was seen by many as a celebration, its 'nose held high', of their embattled national pride. The post-earthquake nationalism that quickly prevailed was a major diversion from the discourse of inclusiveness and minority ethnic assertion that had formed an important part of Nepali political debate for the previous seven years.

The iconisation and reconstruction of the Dharahara was opposed by some, none the less. Three weeks after the quake, the renowned senior cultural scholar Satyamohan Joshi wrote in the leading Nepali-language daily Kantipur that the reason Japan had become a major power in the world despite suffering repeated natural disasters was its people's strong sense of their national identity. But he then went on to argue that despite all the grief that had been expressed about the loss of the Dharahara it was much less important than the scores of Newar-style temples that had also been destroyed. The temples, he said, had their own originality and identity, while the Dharahara did not: 
...it contains no art, no image, no roof, no carving. There is no originality there. It is just an imitation inspired by the thought that we should build a minaret in the style of the Qutb Minar built by the Muslims in Delhi. Nepal has not claimed that it was heritage built by the ancestors. We just regarded it as a pillar in the centre of the city that everyone's eyes fell upon..... If it has to be rebuilt it would be all right to build it in a new style. (Joshi 2015)

However, the temples and palace squares of the Valley's cities were viewed by a wider national public as less their own than the Dharahara-as artefacts specifically of the medieval Newar culture of the Valley, or as ticketed attractions for foreign tourists. A representational dichotomy was very clearly evident: when the need arose to pictorialise the loss of cultural heritage incurred during the 2015 earthquake, the outside world invariably reached for images of collapsed and damaged Newar sites and buildings, but it was the Dharahara that dominated the images presented in the Nepali language media.

Walkowitz and Knauer caution against the notion of a single 'public', pointing out that in many diverse societies factors of race, class, gender and citizenship 'shape individuals' investment in national narratives and the way in which they view themselves in relationship to the public sphere-including debates over public history sites.' They argue that we should conceive of 'multiple publics with divergent and often competing interests and different stakes in how histories are represented' (2009:3). What were the boundaries and contours of the Nepali public that took the Dharahara to its heart as a symbol of both loss and pride? To borrow Simpson's words again, to which Nepali public was the Dharahara 'dear'? To understand this dichotomy it would be necessary to explore the structure and composition of the Nepali public more deeply. 
This lies beyond the scope of the present discussion, ${ }^{\text {xxix }}$ but some preliminary remarks will be offered here none the less.

Some explanations for the relationship between the Dharahara and the public that held it dear may be sought in the nature of the monument itself. First of all, it was tall, visible and fabled: the dominant landmark of the capital city of Nepal. The iconic status it held for nearly 200 years was clearly due in part to the simple fact that it was an object whose simple, primary and very male shape was visible from a wide radius within the capital valley. It was, after all, the tallest structure in the Kathmandu valley for at least six generations of the Nepali public (Sapkota 2015). But it is probably also significant that (despite the Sidewalkers signboard's claim that it was a symbol of religious unity) the Dharahara was perceived to be a secular building, emotionally and politically available to all, regardless of their religious faith. During the Panchayat period (1962-90), when nationalist sentiment was energetically fostered by the monarchical government around the three pillars of Hinduism, the Shah monarchy and the Nepali language, Nepali poets often name checked the monument as an artefact of national history or imagined it as a vantage point from which to survey Nepal. (This was only a poetic conceit, of course, because public access to the tower was not granted until 2061 bs (2004-5). $)^{\mathrm{xxx}}$

The Dharahara was also an important landmark for those who arrived in the capital by road from other parts of the country. The Sundhara locality in which it stood has long been a transport hub, and the ticket offices of many domestic bus companies are still located there. Thus, for many Nepalis arriving in their capital after journeys that may have lasted for more than 24 hours, the Dharahara, along with nearby monuments such as the Ghantaghar (the clocktower of Trichandra College) and the $17^{\text {th }}$-century 
manmade pool of Rani Pokhari, were the first things to be seen, and they became more familiar as emblems of the capital than the pagoda-scape of palaces and shrines that lies just a few minutes' walk away. As the journalist Sarala Gautam told me, 'The heritage sites may be important for people who live here [in Kathmandu] but for those who have come for the first time, or who have been visited once, or have never come here, it's the Dharahara. ${ }^{\mathrm{xxxi}}$

Answers may also be sought in divergences in educational history, socio-economic class, and ethnicity. During the Panchayat period (1962-90), generations of schoolchildren were taught in state schools that Bhimsen Thapa, the creator of the Dharahara, was Nepal's first prime minister and a heroic defender of Nepal's independence and sovereignty, while the Ranas, whose regime succeeded his, were tyrants and obstacles to the nation's development. ${ }^{\text {xxxii }}$ This clear distinction, propagated through the state school curriculum, found new resonance in the aftermath of the 2015 earthquake. Writing in the 'earthquake special' issue of the leading Nepali-language literary magazine Madhupark, the poet Geeta Tripathi harks back to the media reports of people stealing bricks from the ruins of the Dharahara (many of these bricks dated from the 1934 reconstruction and bore the inscription 'Juddha 1991'):

The statue of Juddha Shamsher Rana [that stands] nearby is watching the sorry state of the Dharahara, but it is feeling happy because of the popularity of the bricks that are etched with its name-it is more concerned about having a permanent place in history than it is with people's suffering (Tripathi 2015: 45).

This distinction between the regimes of Bhimsen Thapa and the Ranas who came soon after him may not have been imparted to younger members of the capital's present-day 
elite, many of whom were educated outside the state system after the early 1990s. As a consequence, many of them see the two regimes as one and the same, and they maintain a disdainful attitude to the Dharahara and to the public outpouring of grief at its loss.

The monument's historical and political salience for contemporary Nepal might also be expected to be contested by the Janajati organisations that have been challenging the continued monopolisation of power and privilege by the descendants of the historical Gorkhali elite since the political liberalisation of the 1990s. But many members of minority groups were also a part of the Nepali public that not only held the Dharahara 'dear' but was also receptive to the rallying cry of Gorkhali hill nationalism that led to the re-marginalisation of the country's Madhesi population and a serious deterioration in India-Nepal relations.

\section{Conclusion}

The case of the Dharahara shows that endogenous evaluations of 'heritage' can be inflected by questions of politics, social class, and power. Albala-Bertrand has observed that the exogenous response to a disaster is 'more easily observable' than the endogenous response, and, therefore, 'more amenable to study' (1993: 23). The fact that the 'dearness' of a particular monument to a large portion of a disaster-affected national public was unsuspected by the world heritage authorities, and even disappointed other sections of the same national public, shows that those authorities' understanding of this particular public was limited, as was perhaps also this public's understanding of itself.

A major earthquake strikes. Monuments, houses, schools and infrastructure collapse. Many people die. The first to respond to the emergency are the army, urban 
youth, neighbouring countries. Political leaders are publicly criticised for the inadequacy of their preparedness and the slowness of their response. People speak, read and write of the unifying and leveling effects of the disaster. Some begin to imagine a future under a new set of leaders with a new political culture. When the leaders do respond, they respond politically: they come together to draft and promulgate a long-awaited constitution. This is seen by some to renege on promises and commitments made eight years earlier. In particular, it alienates the Madhesi population of the lowlands, leading to public protests, violence, and a major international dispute. The leaders manage to unite the non-elite majority of the hill population behind them, a population for whom a tall white tower in Kathmandu, erected in an act of 'state-sponsored triumphalism' (Winter 1999) two hundred years ago - is revealed to be more dear (Simpson 2013) than anyone knew, both as a symbol of their loss and an icon for the restoration of that loss. The immediate loss is of lives and buildings, but this public also mourns a dimly remembered glorious national pride, especially as the promulgation of a new constitution provokes what they are told is a 'blockade' by their powerful southern neighbour. Thus, as the moment of critical juncture passes and the likelihood of fundamental political and cultural change fades, old memories and old forgettings (Abramson 1999) are drawn upon, in order to reinstate in strengthened and 'accelerated' forms the power structures and hierarchies of the predisaster status quo.

\section{References}

Abramson, Daniel. 1999. 'Make History, Not Memory’ Harvard Design Magazine No. 
9 / Constructions of Memory: On Monuments Old and New, Fall 1999. http://www.harvarddesignmagazine.org/issues/9/make-history-not-memory

Albala-Bertrand, J.M. 1993. Political Economy of Large Natural Disasters. With special reference to developing countries. Oxford: Clarendon Press.

Barthes, Roland 1964. 'The Eiffel Tower' in A Barthes Reader, edited by Susan Sontag, pp. 236-50. New York: Hill and Wang.

Bhattarai, Atul 2018. 'Storeyed past: the movement to rebuild earthquake-hit Nepal's most iconic heritage structure' The Caravan, March 2018: 50-61.

Brown, Percy 1912. Picturesque Nepal. London: Adam and Charles Black.

Chimariya, Santosh 2015. 'Timro abhav khatkirahnecha' [Your absence will continue to discomfit us] Setopati 21 Baisakh 2072 b.s.

Dixit, Ajay 2015. 'Tyo seto gagan chuli' [That white sky peak] Nepal Patrika, 17 May.

Elsner, Jas 2003. 'Iconoclasm and the preservation of memory' in Monuments and Memory, Made and Unmade, edited by Robert S. Nelson and Margaret Olin, pp. 20931. Chicago and London: Chicago University Press

Gautama, Sarala 2015. 'Dhalyo re ni dharahara!' [They say the Dharahara fell down!] Kantipur Koseli 2 Jeth 2072 b.s. [30 May 2015] 
Hutt, Michael 2012. 'Singing the new Nepal' Nations and Nationalism 18.2: 306-25.

Hutt, Michael and Pratyoush Onta (eds) 2017. Political Change and Public Culture in post-1990 Nepal. New Delhi: Cambridge University Press.

Joshi, Satyamohan 2015. 'Euta sanskritik kranti chahieko cha' [A cultural revolution is needed] Kantipur 16 May 2015.

Landon, Perceval 1928. Nepal. London: Constable and Co.

Lotter, Stefanie 2018. 'Moving images: commemorative tattoo art in the aftermath of the Nepal earthquakes in 2015'. Presentation to the Britain-Nepal Academic Council Nepal Study Day, University of Durham, 17 April.

Nelson, Robert S. and Margaret Olin 2003. 'Introduction' in Monuments and Memory, Made and Unmade, edited by Robert S. Nelson and Margaret Olin, pp. 1-10. Chicago and London: Chicago University Press.

Nepal, Kishor 2015. 'Dharaharale phailaeko tras' [The terror spread by the Dharahara] Kantipur 12 May 2015.

Nepali, Chittaranjan 1965/6 [2022 b.s.] Janaral Bhimsen Thapa ra tatkalin Nepal. [General Bhimsen Thapa and the Nepal of that time] Kathmandu: Ratna Pustak Bhandar. 
Nyaupane, Damodar 2016. 'Yasto banne cha nayam Dharahara' [This is how the new Dharahara will be built] Kantipur, 1 August.

Nyaupane, Suresh Raj 2015a. 'Kasle banaune dharahara?' [Who will repair the Dharahara?] Kantipur, 3 August.

Nyaupane, Suresh Raj 2015b. 'Doshi mahanagarpalika' [Guilty city council]. Nepal Patrika 11 May.

Nyaupane, Tuphan 2015. 'Purano shilpa, nayam nirman' [Old craft, new construction] Himal Khabar Patrika 20-26 Baisakh 2072 b.s.

Ojha, Anup 2016. “"Citizens fund” for new Dharahara' The Kathmandu Post, 17 February.

Oliver-Smith, Anthony 1996. 'Anthropological research on hazards and disasters' Annual Review of Anthropology 25: 303-28.

Oliver-Smith, Anthony and Susanna M. Hoffman 2001. 'Why anthropologists should study disasters' in Hoffman, Susanna M. and Anthony Oliver-Smith (eds) Catastrophe and Culture: the Anthropology of Disaster pp. 3-22. Santa Fe: School of American Research Press and Oxford: James Currey. 
Pelling, Mark and Kathleen Dill 2010. 'Disaster politics: tipping points for change in the adaptation of socio-political regimes' Progress in Human Geography 34(1): 2137.

Phillips, Rachel 2003. 'Settler monuments, indigenous memory: Dis-membering and re-membering Canadian art history' in Monuments and Memory, Made and Unmade, edited by Robert S. Nelson and Margaret Olin, pp. 281-304. Chicago and London: Chicago University Press.

Pokhrel, Harihar 2015/16 [2072 b.s.] Mahabhukampa 2072 [Great earthquake 2072]. Kathmandu: Brother Books.

Prince, Samuel 1920. Catastrophe and Social Change. New York: Columbia University.

Rademacher, Anne M. 2009. 'Marking Remembrance: Nation and ecology in two riverbank monuments in Kathmandu' in Walkowitz and Knauer eds, Contested Histories in Public Space: Memory, Race, and Nation, pp. 229-48. Durham and London: Duke University Press.

Sama, Balkrishna 1972/3 [2029 b.s.] Mero Kavitako Aradhan Upasana 2 [My worship of poetry, part 2]. Kathmandu: Sajha Prakashan.

Sapkota, Janakraj 2015. 'Dhalyo Dharahara' [The Dharahara has fallen] Nepal Patrika, 3 May. 
Shrestha, Siddhicharan 2016/17 [2073 b.s.], Bhimsen Thapa (Aitihasik Mahakavya) [Bhimsen Thapa (historical epic poem)]. Kathmandu: Nepal Prajna-Pratisthan.

Shrestha, Siddhicharan 1974/5 [2031 b.s.] Kopila [Flowerbud]. Kathmandu: Harek Nayam Pustak Bhandar.

Simpson, Edward 2013. The Political Biography of an Earthquake. Aftermath and amnesia in Gujarat, India. London: Hurst and Co.

Sitaula, Devendraprasad 2015. 'Durbal dharahara durbal netritva' [Weak Dharahara weak leadership] Annapurna Post, 1 May 2015.

Slusser, Mary Shepherd 1982. Nepal Mandala. A Cultural Study of the Kathmandu Valley. Vol. 1: Text. Princeton: Princeton University Press.

Tripathi, Geeta 2015. 'Mahabhukampaka atmavihin anuragharu' [Soulless devotions of the great earthquake] Madhupark 48.1: 43-5.

Walkowitz, Daniel J. and Lisa Maya Knauer 2009. 'Introduction: Memory, Race, and the Nation in Public Spaces' in Contested Histories in Public Space: Memory, Race, and Nation, pp.1-27. Durham and London: Duke University Press.

Winter, Jay 1999. 'Remembrance and Redemption' Harvard Design Magazine No. 9 / Constructions of Memory: On Monuments Old and New, Fall 1999. 
http://www.harvarddesignmagazine.org/issues/9/remembrance-and-redemption

Wood, Nancy 1994. 'Memory’s remains: Les lieux de mémoire' History and Memory 6.1: $123-49$.

\section{ILLUSTRATIONS}

1. The Bagh Darbar and the Dharahara, sketched by a member of the entourage of Prince Waldemar during a visit to Kathmandu in 1844. From the 'Heidelberg Historic Literature-digitized' collection at https://digi.ub.uniheidelberg.de/diglit/mahlmann1853bd1/0222/.

2. The Dharahara, seen from the north across the rooftops of pre-highrise Kathmandu in November 1987. Photograph: Michael Hutt

3. Information board in English erected by Sidewalkers Pvt Ltd at the site of the Dharahara, July 2015. Photograph: Michael Hutt

4. Information board in Nepali erected by Sidewalkers Pvt Ltd at the site of the Dharahara, July 2015. Photograph: Michael Hutt

5. The remains of the Dharahara, July 2015. Photograph: Michael Hutt

6. The design on a Dharahara t-shirt, purchased by the author in Asan bazaar, Kathmandu, in 2017. Photograph: Michael Hutt

7. A replica Dharahara, on the Prithvi Highway near Malekhu, December 2017. Photograph: Michael Hutt

8. A replica Dharahara at the Shahid Gate traffic intersection, Kathmandu. Photograph: Michael Hutt. 
9. Artist's impression of a reconstructed Dharahara, from The Kathmandu Post, 1 August 2016. http://kathmandupost.ekantipur.com/news/2016-08-01/designsof-new-dharahara-made-public.html

i This paper is based upon research conducted as a part of the project 'After the Earth's Violent Sway: the tangible and intangible legacies of a natural disaster' funded by the UK's Global Challenges Research Fund through the Arts and Humanities Research Council. Grant number AH/P003648/1. All translations from Nepali are the author's own. My thanks go to Stefanie Lotter, Edward Simpson, John Whelpton, Pratyoush Onta, Yogesh Raj, Tek Bahadur Shrestha, Rabi Charan Shrestha, Abhi Subedi, Geeta Tripathi, Satyamohan Joshi, and the two anonymous reviewers of an earlier draft of this article.

ii A key strand of the 'Violent Sway' project is the creation of an extensive digital archive of materials on the 2015 Nepal earthquake [https://digital.soas.ac.uk/SWAY], 
which will constitute a new section of the wider SOAS Digital Library. The research for the present article draws heavily on published material gathered for this archive during brief research visits to Nepal in 2015 and 2016 and a four-month stay in 20172018, as well as on interviews and conversations with journalists, writers, politicians and a wide range of ordinary citizens over a similar period.

iii The Dharahara's place in Nepal's national history is also assured by a legend according to which Jang Bahadur Kunwar, whose 1846 massacre of all his rivals marginalized the Shah monarchy and established the rule of the Rana family which lasted until 1951, jumped on his horse from the top of the Dharahara to the pavementfor a wager in some versions of the story, at the command of Crown Prince Surendra in others.

iv The first two Shah monarchs of the $19^{\text {th }}$ century were minors. The first, Girvan Yuddha Shah, died in 1816 at the age of 19 and was succeeded by the three year old Rajendra Bikram Shah.

${ }^{\mathrm{v}}$ The Dharahara that survived into the $20^{\text {th }}$ century was often referred to in English as 'Bhimsen's Tower' or 'Bhimsen's Folly', and sometimes in Nepali as Bhimsen Stambha.

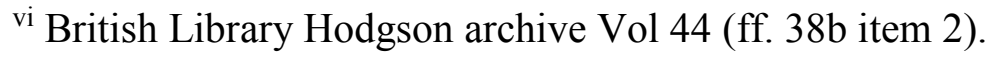
$\underline{\text { www.digitalhimalaya/hodgson }}$

vii Lalit Tripura Sundari, the youngest queen of Ran Bahadur Shah, was widowed at the age of 12. She was the regent queen during the minorities of kings Girvan Yuddha and Rajendra, and died on 6 April 1832.

viii The Sidewalkers information boards at the base of the Dharahara inform visitors, rather confusingly, that the tower was built by the 'First Prime Minister of Nepal Bhimsen Thapa in 1825 AD in the name of the Shah queen Lalit Tripura Sundari.' 
${ }^{\text {ix }}$ Frederik William Waldemar (1817-45), Prince of Prussia, arrived in Kolkata in 1844 and sketches from his subsequent journey across north India and Nepal may be viewed in the online archive of the University of Heidelberg. [http://digi.ub.uniheidelberg.de/diglit/mahlmann1853bd1/0222?sid=08bf1 c60bc60fb0564ee7252af3633

e1. The sketch of the Bagh Darbar reproduced as Plate 1 clearly shows a lone Dharahara; the text that accompanies the sketch records that a second tower had collapsed in the 1833 earthquake and that its debris still covered the site. My thanks to Stefanie Lotter for alerting me to the existence of this resource.

x Bhimsen's creation of the Dharahara was probably also inspired by some measure of personal conceit. He already had caged tigers at the gates of his Bagh (Tiger) Palace: why not a Mughal minaret too? The Shah and Rana elites had adopted other strands of Persianate cultural pretension, including a special honorific form of address and a special verb conjugation for the actions of family members.

${ }^{x i}$ Dixit (2015), who grew up very close by, recalls that the bugle was sounded from the Dharahara to mark Democracy Day on the seventh day of the month of Phagun every year after the end of the Rana regime.

xii Personal communication, Kathmandu, 1 August 2016.

xiii Acharya Prabha, 'E mero Dharahara' [Oh my Dharahara], Setopati, 26 April 2015 http://www.archive.setopati.com/sahityapati/27408

xiv Niru Tripathi, 'Albida Dharahara' [Farewell Dharahara], Setopati 26 April 2015, http://www.archive.setopati.com/sahityapati/27394. See also Pushparaj Paudel, 'Priya Dharahara [Dear Dharahara], Setopati, 25 April 2015, http://www.archive.setopati.com/sahityapati/27376 
xv 'Dharaharako inta chorna mahasachivko nirdeshan' [Chief Secretary's instruction to steal Dharahara bricks] http://www.onlinekhabar.com/2015/04/271527, accessed 21 May 2016.

xvi 'Dharaharaka inta damping sait lagindai sarkari adhikari bhanchan: matlab chaina' [As Dharahara bricks are taken away to a dumping site, a government official says: it doesn't matter], www.onlinekhabar.com/2016/05/429704, 19 May 2016, accessed 21 May 2016.

xvii Anon. 'Cost of corruption' The Kathmandu Post 9 August 2015.

xviii Six days after the earthquake, it was reported that fifty bodies had been dug out of the ruins so far ('Dharaharabata pachas shav nikaliyo' [Fifty bodies removed from Dharahara], Kantipur 1 May 2015). Sapkota (2015) gives a final figure of 155 fatalities, Ojha (2016) of 180.

xix 'Dharaharama banchepachi: ghau birsera sapna pachyaundai' [After surviving in the Dharahara: forgetting wounds, pursuing a dream] Nagarik News 23 April 2016. Other Dharahara survivor stories include Kamansingh Khadka, 'Aphaimathi Dharahara khasdai gareko dekhda' [Seeing the Dharahara falling upon me] Shabda Sanyojan 12.2: 293-7; 'Dharahara chadhnu aghi usle gareko antim myasaj' [The last message he sent before climbing the Dharahara] (Setopati 25 April 2016); Swarup Acharya, 'Dharaharale malai nilena' [The Dharahara did not swallow me] (Kantipur 30 April 2015). Four of the 16 survivor stories collected by Harihar Pokharel (2072: 109-33) concern Dharahara survivors. See also 'Surviving the fall', Nepali Times 12-18 February 2016 [http://archive.nepalitimes.com/article/Nepali-Times-Buzz/survivingthe-fall-from-Dharara,2865] A similar story appeared on the British news site Daily Mail Online $\quad$ on 28 April 2015: http://www.dailymail.co.uk/indiahome/indianews/article-3059671/Man-atop-nine- 
storey-Dharahara-tower-Kathmandu-quake-struck-lives-tell-tale-survival.html, accessed 16 May 2016.

xx 'Dharahara's replica being built in Nawalparasi, Setopati, 25 April 2016 [http://setopati.net/society/13408, accessed 25/4/2016]. 'Navalparasima 25 lakh kharcha garera banaindai cha yasto Dharahara' [This Dharahara is being built in Nawalparasi at a cost of 25 lakhs]. http://sajhasabal.com/nawalparasi/news/dharaharain-nawalparasi/, 25 April 2016.

xxi youtube.com $/$ watch? $v=w \_S c C E K 05 f Q$. See also the short drama on Youtube entitled 'Dharahara A Dream' by Sunil Young $\underline{\text { https://www.youtube.com/watch?v=9xEFvztUURk }}$

xxii The reconstruction of Kasthamandap, reputedly Kathmandu's oldest building which gave the city its name, remained mired in controversy at the time of writing. See Bhattarai (2018).

xxiii "'Dharahara" rastrako parichay ho, janatako sahabhagitama punanirman' [Dharahara is a feature of the nation, reconstruction with public involvement] http://medianp.com/2016/5/84874.html, accessed 5/6/2016. 'Dharahara punanirmanka lagi kosh sthapana' [Fund established for Dharahara reconbstruction] https://hamrakura.com/news-details/7838/2016-05-01 (1 May 2016); 'Dharahara tin varshabhitra banaune' [Dharahara to be built within three years] http://ujyaaloonline.com/news/57146/dharahara/. 8 May 2016 [SP160516A3] xxiv 'Dharahara Reconstruction Campaign in limbo over lack of fund' Republica 29 March 2016, xxv ‘Kasle banaune Dharahara?' [Who will rebuild the Dharahara?] by Suresh Nyaupane. Nepal Patrika weekly, http://ekantipur.com/np/2072/4/18/fullstory/413956.html. Accessed 3/8/15. 
xxvi These are: Kathmandu Durbar Square; Bhaktapur Durbar Square; Patan Durbar Square; Swayambhu Stupa; Pashupati Temple; Bouddha stupa; Changu Narayan temple.

xxvii 'Sketch of to-be-built Dharahara made public' (Post report) The Kathmandu Post, 2 August 2016.

xxviii As reported in The Kathmandu Post on 27 December 2018.

[https://kathmandupost.ekantipur.com/news/2018-12-27/pm-oli-lays-foundation-fordharahara-reconstruction-amid-protest-from-cultural-activists.html]. The report describes the original Dharahara inaccurately as an ' $18^{\text {th }}$-century' structure and records that the laying of the foundation stone was accompanied by protests by cultural activists objecting to the use of concrete in the reconstruction.

${ }^{\text {xxix }}$ For a collection of essays on the relationship between political change and public culture in Nepal see Hutt and Onta (eds) 2017.

${ }^{x x x}$ Siddhicharan Shrestha's rapturous account of the beauty of the Kathmandu Valley as seen from the top of the tower was published shortly after the 1934 earthquake and is probably the most famous poem to adopt this particular trope. Siddhicharan Shrestha: 'Dharaharamathibata' [From the top of the Dharahara], from Shrestha 2031 b.s.: 19-20. Poem first published in Sharada in 1935-6 [1992 b.s.])

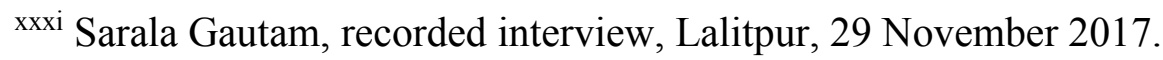

xxxii Geeta Tripathi, personal communication, Kathmandu, 6 December 2017. 